\title{
Honor Scale: A Study for Reliability and Validity
}

\author{
Suzan Ceylan-Batur ${ }^{1}$, Nuray Sakallı Uğurlu ${ }^{2}$
}

Ceylan-Batur, S. ve Sakallı Uğurlu, N. (2019). Honor scale: A study for reliability and validity. Nesne, 7(15), 236-253. DOI: 10.7816/nesne-07-15-06

\section{Keywords}

Honor, honor culture, honor scale, reliability, validity

\section{Anahtar kelimeler} Onur, onur kültürü, onur ölçeği, güvenirlik, geçerlik

\begin{abstract}
The purpose of the study was to adapt the Honor Scale (HS), which is composed of four different honor codes including feminine honor, masculine honor, family honor, and moral integrity (Rodriguez Mosquera, Manstead, \& Fischer, 2002b) by adding culture-congruent items, and examine the reliability and validity of the emerging scale. In line with this purpose, three studies were conducted. Study 1 ( $N=57 ; M_{\text {age }}=33.46$, $S D_{\text {age }}=15.53$ ) was carried out to acquire additional culture-congruent items, which was used in the Study 2 $\left(N=422 ; M_{\text {age }}=28.84, S D_{\text {age }}=6.84\right)$ on the purpose of assessing the reliability and validity of HS . Moreover, Study $3\left(N=818 ; M_{\text {age }}=21.30, S D_{\text {age }}=2.15\right)$ was conducted to evaluate the generalizability of the Study 2, by using only the original HS items. The exploratory and confirmatory factor analyses suggested a three-factor solution for the scale (feminine honor, masculine honor, and moral integrity). Cronbach's alpha coefficients for the scale was .94 (Study 2) and .90 (Study 3); and ranged from .82 to .92 (Study 2) and .85 to .88 (Study 3) for the subscales. In conclusion, the results of the psychometric analyses show that the Turkish version of HS is a reliable and valid measurement tool for the studies relevant to this topic.

\section{Onur Ölçeği: Geçerlik ve Güvenirlik Çalışması \\ Öz}

Bu çalışmanın amacı, kadınlık, erkeklik, aile ve ahlaki bütünlük olmak üzere dört onur kodundan oluşan Onur Ölçeği'ni (Rodriguez Mosquera, Manstead ve Fischer, 2002b) kültüre uygun yeni maddeler ekleyerek Türkçe'ye uyarlamak ve oluşan ölçeğin geçerlik ve güvenirlik bulgularını incelemektir. Bu amaçla üç farklı çalışma yapılmıştır. Mevcut kültüre uygun yeni maddeler eklemek amacıyla 1 . Çalışma $(N=57$; Ort.yas $=$ $33.46, S=15.53)$, yeni maddelerin eklendiği ölçeğin geçerlik ve güvenirliğini test etmek için 2 . Çalışma $(N$ $=422 ;$ Ort.yas $=28.84, S=6.84$ ) yapılmıştır. Ayrıca, bu çalışmadan çıkan sonuçların genellenebilirliğini anlamak amacıyla, sadece orijinal maddelerin kullanıldığı 3. Çalışma $(N=818 ;$ Ort. yas $=21.30, S=2.15)$ yapılmıştır. Açımlayıcı ve doğrulayıcı faktör analizi bulguları, üç faktörlü bir yapıya (kadınlık, erkeklik ve ahlaki bütünlük) işaret etmektedir. Ölçeğin iç tutarlık katsayısının $\alpha=.94$ (2. Çalışma), $\alpha=.90$ (3. Çalışma), ölçeğin alt faktörleri için $\alpha=.82$ ve $\alpha=.92$ (2. Çalışma) ve $\alpha=.85$ ve $\alpha=.88$ (3. Çalışma) arasında değiştiği bulunmuştur. Sonuç olarak, psikometrik özelliklere dair bulgular ölçeğin Türkçe formunun konu ile ilgili yapılacak araştırmalarda kullanılabilecek düzeyde geçerlik ve güvenirliğe sahip olduğunu göstermektedir.
\end{abstract}

\section{Article History}

Arrived: October 15, 2018

Revised: November 6, 2019

Accepted: November 26, 2019
Author Note. This research was supported by Scientific and Technological Research Council of Turkey (TUBITAK 1001-114K347, Project Manager: Prof. Dr. Nuray Sakallı Uğurlu, Scholarship student: Suzan Ceylan). Author Note. This publication uses data collected within the framework of first author's $\mathrm{PhD}$ thesis.

\footnotetext{
${ }^{1}$ Asst. Prof., TOBB University of Economics and Technology, Department of Psychology, scbatur(at)etu.edu.tr, ORCID: 0000-0003-2073-7598
} ${ }^{2}$ Prof., Middle East Technical University, Department of Psychology, ORCID: 0000-0003-4984-8427 
Honor cultures are the social settings where honor concept is related to status, precedence, and reputation (Pitt-Rivers, 1965). Italy (Bettiga-Boukerbout, 2005), Spain (Rodriguez Mosquera, Manstead, \& Fischer, 2002b), Turkey (Sakall1-Uğurlu \& Akbaş, 2013), Lebanon (Hoyek, Sidawi, \& Mrad, 2005), Egypt (Abu-Lughod, 1986), Morocco (Gregg, 2007), Arab world in general (Kulwicki, 2002), and South America (Nisbett \& Cohen, 1996) can be given as examples of honor countries. In these cultures, honor is defined as "the value of a person in his own eyes, but also in the eyes of his society" (Pitt-Rivers, 1965, p. 21). In order to examine the honor concept, researchers developed various scales measuring to what extent the honor is endorsed by members of honor cultures. The aim of the current study is to adapt one of these scales, namely Honor Scale (HS, Rodriguez et al., 2002b), into Turkish, by including new culture-congruent items along with the original items. Because honor is a concept which may contain distinct meanings in different cultures (for a review, see Sakallı Uğurlu, \& Akbas, 2013), the present study aims to adapt not only the original HS items produced in Spain, but also generate new items which are compatible with Turkish culture. In this sense, this study includes both an adaptation of the original HS and development of new items. Generating an honor scale in this culture is aimed for two reasons: First, it is important to examine the structure of honor in Turkey to explore the consistency between different honor countries (e.g., Spain vs Turkey). Second, the scale may be helpful for researchers to study honor and its association with other social psychological constructs in Turkish culture and/or other countries.

Previous research suggests that honor is known as the 'public recognition' of an individual's status in the society (Moxnes, 1996, p.20). In that sense honor becomes a measure of social worth and a vital characteristic of an individual (Kardam, 2005; Rodriguez Mosquera, Fischer, Manstead, \& Zaalberg, 2008). In honor cultures, getting an honorable status requires effort and struggle. People might gain or lose it through their appropriate or not appropriate behaviors (Peristiany, 1965). There are acceptable and not acceptable behaviors determined by particular communal rules, namely honor codes in the society. These honor codes are stated as "deeply internalized, so that people automatically respond to events and build reputations, personalities, or selves in its terms." (Gregg, 2005, p.92). They are composed of various norms and values, which differentiate an honorable act from a dishonorable one (Rodriguez Mosquera et al., 2002b).

In the literature, Rodriguez Mosquera et al. (2002a, 2002b, 2008) indicated the importance of four different codes in honor, namely feminine, masculine, family, and moral integrity. The feminine honor code is based on female chastity. In honor cultures, the sexuality of women is under control by men (and older women) in the family. The feminine honor code limits how a woman dresses, how she spends her free time, whether she can attend her education, or whether she can go to work (Sen, 2005). The masculine honor code refers to a set of values and norms that determine how a man should be. A man is obliged to be strong, tough, fearless, dominant, autonomous, and brave enough to protect women and others in the family (Fischer, 1989; Nisbett \& Cohen, 1996; Thompson \& Pleck, 1986). The family honor code is a set of values and norms related to the reputation of one's family name (Rodriguez Mosquera et al., 2002a, 2002b). It is related to family's recognition in terms of moral values in a society (Sev'er \& Yurdakul, 2001). The moral integrity imposes that since people in honor cultures carry highly collectivist norms (Üskül, Cross, Sunbay, Gerçek-Swing, \& Ataca, 2012), they give importance to "strengthening of social bonds and the maintenance of interpersonal harmony, such as generosity, honesty or hospitality" (Rodriguez Mosquera et al., 2002b, p. 147). 
The initial attempt to measure all honor codes in one scale was made by Rodriguez Mosquera et al. (2002b). They developed an Honor Scale (HS) to compare honor concern of participants in Spain (an honor culture) and Netherlands (where honor is of less central significance). Afterwards, Guerra, Gouveia, Araújo, Andrade, and Gaudêncio (2013) published a short version of the honor scale (16 items, 4 in each) in the Brazilian setting. In the literature, several other scales have been developed to measure honor concept, based on various aspects of the construct. For example, Vandello, Cohen, Grandon, and Franiuk (2009) developed Honor Endorsement Index (HEI) to assess cultural differences (Chile vs. Canada) in terms of gender-specific honor values. Barnes, Brown, and Osterman (2012) developed Honor Ideology for Manhood (HIM) scale to measure the masculine dimension of honor. Later, Barnes, Brown, Lenes, Bosson, and Carvallo (2014) introduced a feminine counterpart to the HIM, the Honor Ideology for Womanhood (HIW) scale. The HIM and HIW scales differ from the HS by measuring the ideological aspect of honor concept, and the HEI differs from HS by assessing only female and male honor, whereas HS is more concerned with to what extent individuals feel bad when they violate the feminine honor, masculine honor, family honor, and moral integrity codes.

In addition to the scales above, researchers developed scales to assess honor concept in Turkey. For example, Işık and Sakallı-Uğurlu (2009) developed Attitudes toward Honor Scale (AHS), which involved only women honor, called "nатиs" in Turkish. Recently, Elgin (2016) adapted Honor Value Scale (Rodriguez Mosquera et al., 2008) into Turkish for his doctorate thesis. The scale focuses on the importance of social image of an individual (e.g., "Others see me as someone who deserves respect") and his/her family (e.g., "Defend my family from criticism"). Akbaş (2016) also developed Honor Based System Justification Scale focusing on women's disadvantaged position due to honor-system for her doctorate thesis.

Considering Turkish studies above, the existing literature in Turkey fails to provide an honor scale including four facets of honor, namely, feminine, masculine, family, and moral integrity. Therefore, the aim of the present study to adapt the HS (Rodriguez Mosquera et al., 2002b) into Turkish. Over the past decade, most research has emphasized the consideration of honor as a multi-dimensional construct. Therefore, due to Turkish version of HS, we can also examine whether the tetrad-honor structure exists in Turkey. Furthermore, considering possible cultural differences between Turkey and other honor countries we aimed to include additional items to the original HS (Rodriguez-Mosquera et al. (2002b) to provide a valid and a reliable scale compatible with Turkish culture. To this end, we conducted three consecutive studies. In Study 1, we run a series of semi-structured interview to generate new items. In Study 2, we tested the reliability and validity of HS, which includes both original items and new items generated from Study 1. In Study 3, we included only original HS items in order to examine whether the honor construct would emerge as similar to the structure existed in Study 2.

\section{Study 1}

This qualitative study was carried out in order to provide new and culture-congruent items, which will be used in the Study 2, on the purpose of developing Turkish honor scale.

\section{Participants}

\section{Method}

The study sample consisted of 57 (26 female; 31 male; $\left.M_{\text {age }}=33.46, S D_{\text {age }}=15.53\right)$ participants from various age groups, and education levels (see Table 1). 
Table 1

Number of Participants based on Education Level, Age Group, and Gender

\begin{tabular}{|c|c|c|c|c|}
\hline \multirow[t]{2}{*}{ Education Level } & \multicolumn{2}{|c|}{ High school or less } & \multicolumn{2}{|c|}{ University or more } \\
\hline & Women & Men & Women & Men \\
\hline Age Group & & & & \\
\hline Under 26 & 5 & 3 & 11 & 5 \\
\hline $26-49$ & 2 & 10 & 4 & 8 \\
\hline 50 and over & 3 & 3 & 1 & 2 \\
\hline
\end{tabular}

\section{Measures}

In order to conduct semi-structured interviews, several questions were prepared by a joint work with the advisor.

\section{Procedure}

After the study was approved by the Human Research Ethics Committee of Middle East Technical University, participants were reached through snowball technique. Before proceeding to ask interview questions, all of the participants were informed about the study and asked for voluntary participation. All interviews were audio-recorded for subsequent transcription by the researcher. Prior to beginning interview, demographic data (age, hometown, education level, and occupation) was obtained. During the interviews, in case of not being understood, questions were probed for better comprehension. Interviews took approximately 30 minutes.

\section{Results}

The first question was about the definition of honor. Around one third (35\%) of the participants associated honor with woman and sexuality, while other $35 \%$ of the participants associated with dignity codes like honesty, truthfulness, and fairness. On the other hand, $24 \%$ of the participants defined honor through both. Only $6 \%$ of the participants used other concepts apart from women and dignity, such as religiosity, in order to define honor. Furthermore, cross-tab analyses revealed significant differences $(p<$ .01) between two levels of education (i.e., high-school or less, and university and more), in terms of defining honor as sexuality/women vs. dignity. That is to say, graduates from high-school or lower grades associate honor more with women and sexuality, whereas graduates from university or higher degrees defined it more with dignity codes.

The second question asked participants to give examples of how someone loses his/her honor. As examples, half of the participants (51\%) expressed 'losing virginity', and almost other half (42\%) of the participants expressed 'infidelity'. The results may indicate that Turkish participants mainly remember issues relevant to women issues when they are asked how someone loses her/his honor. Losing honor concept may reflect women's honor (namus) as suggested by Sakall1-Uğurlu and her colleagues (Işık \& Sakall1- Uğurlu, 2009; Sakall1-Uğurlu \& Akbaş, 2013).

The third question asked participants what they think about people who lost their honor. Results showed that $42 \%$ of the participants reported that they would condemn them, whereas other $42 \%$ of the 
participants told that they would not be prejudiced. Besides, $10 \%$ of them told that they would feel sorry for those who lost their honor. The rest of the participants $(6 \%)$ did not comment on this question.

The following question was related to public viewpoint toward honor. In other words, participants were asked how the honor is defined in this culture, that is, how other people perceive honor. The majority of the participants $(70.2 \%)$ reported that honor in this society is associated with women and sexuality; while only $2 \%$ of them expressed that it was defined through dignity context. Since there is a significant difference ( $p<.001$ ) between individual opinion, and his/her imagination of society that she/he lived in, this finding points to the pluralistic ignorance effect (see Miller \& Prentice, 1994; Prentice \& Miller, 1996), which refers to a situation in which people erroneously believe that most others in the society accept a norm except for themselves.

These were the findings of the interview analyses. The second step was to examine the sentences used by the participants when they were answering the questions. For example, when we asked a participant to give examples of "how someone loses his/her honor", if the participant answered as "a person loses his/her honor if he/she has one-night stands", we included this answer as an item. In addition, we included several items based on the existing literature. For example, Kardam (2005) published a very comprehensive report related to honor concept and related values in Turkey. The report inspired us to generate items such as "I would feel bad, if I got divorced and married with someone else". Further information related to items is included in Study 2.

Afterwards, a reviewer team including people unaware from the research questions (yet given a very brief explanation) was formed to examine the items in terms of their ambiguity, repetitiveness, integrity of meaning, and sentence smoothness. By the end of this stage, the items have taken the final shape.

\section{Study 2}

After Study 1, which provided new culture-congruent items for honor codes, we aimed to test validity and reliability of HS (Rodriguez-Mosquera et al., 2002b) with newly added items in Turkish culture.

\section{Method}

\section{Participants}

The study consisted of 422 participants ( 251 women, and 169 men). Two participants did not report their gender. The age of participants ranged from 19 to $63(M=28.84, S D=6.84)$. The mean for economic status of the participants was 3.90, in a 1-to-6 scale, greater score presents higher economic condition. The religiosity level of the participants was 2.69 , in a 1-to-6 scale, greater score presents higher religiosity. The mean of the political orientation was 2.72 , in a scale presenting extreme right at the 6-point side, and extreme left at the 1-point side.

\section{Measures}

Honor Scale: The HS (Rodriguez Mosquera et al., 2002b) measures individuals' honor concern including four different facets: feminine honor, masculine honor, family honor, and moral integrity. First, 27 items of 
the original HS were translated into Turkish. Then, it was back translated by the researcher, and two bilingual contributors. Second, new 36 items (generated in Study 1) were added to the item pool.

The final analysis was conducted on 63 items; only two of them were reversed items. Some sample items for each code are as follows: How bad would I feel "if I had sexual relations before marriage" (feminine honor code); "if I were unable to support my own family economically" (masculine honor code); "if I did not keep my word" (moral integrity code); "if I did something to damage my family's reputation" (family honor code). The participants were asked to rate how bad they would feel on a 6-point Likert-type Scale, where $1=$ 'not at all bad' and $6=$ 'very bad'. Higher scores indicate more concern for honor.

Honor Endorsement Index (HEI): Nine items HEI measures participants' endorsement of honor (Vandello et al., 2009; for Turkish version see Glick, Sakall1-Uğurlu, Akbaş, Metin-Orta, \& Ceylan, 2016). The index has two sub-scales in order to differentiate gendered aspects of honor. A sample item for female honor $(H E I W)$ is "A woman must be pure and honest" and a sample item for male honor (HEIM) is "A man must defend his honor at any cost". The participants were asked to rate how much they agree or disagree with the items on a 6-point Likert-type Scale, where $1=$ 'Completely disagree' and $6=$ 'Completely agree'. Higher scores indicate greater honor endorsement $(\alpha=.86)$.

\section{Procedure}

The study was approved by the Human Research Ethics Committee of Middle East Technical University. The final version of the scale was uploaded to internet via a software program (Qualtrics, LLC.). The link was shared with people through mail groups, social media, and requests from lecturers in Middle East Technical University, and Ankara University. All of the participants were informed about the study and asked for voluntary participation. Afterwards, they were directed to the researcher in case they need further information.

\section{Data Analysis}

In the current study, we investigated the factorial structure of the scale by conducting Exploratory Factor Analysis (EFA) and confirmatory factor analyses (CFA). First, we applied The Kaiser-Meyer-Olkin (KMO) and Bartlett's Test of Sphericity (BTS) to decide whether the data suited for factor analysis. Then, we conducted EFA using principal component analysis to determine the dimensional structure of the scale. The internal consistency of the scale was measured by Chronbach's alpha coefficient. Afterwards, we performed CFA to evaluate whether the emerging factor-structure revealed good fit indices.

\section{Results}

The data were screened for outliers. Standard z-scores were computed and 5 cases with z- scores below -3.29 were excluded. As a result, 422 subjects remained for the analyses.

\section{Validity of HS}

Factor Structure: An exploratory factor analysis was conducted on 63-item honor scale. The varimax method was applied as the rotation method. The Kaiser-Meyer-Olkin (KMO) and Bartlett's Test of Sphericity have shown that data is convenient for the factor analysis, $K M O=.92, \chi 2(435)=6419.92, p<$ 
.001 (see Tabachnick \& Fidell, 2007). The maximum number of iterations was set as 30 and the cut-off point for loadings was set at .40 .

Table 2

Factor loadings, item-total correlations, explained variances, eigenvalues, Cronbach's alphas, and items' means per factor

\begin{tabular}{|c|c|c|}
\hline Factor / Item & $\begin{array}{c}\text { Factor } \\
\text { Loadings }\end{array}$ & $\begin{array}{r}\text { Item-Total } \\
\text { Correlations }\end{array}$ \\
\hline \multicolumn{3}{|c|}{$\begin{array}{l}\text { Factor 1: Feminine Honor (Explained variance }=29.70 \% ; \text { Eigenvalue }=8.91 ; \alpha=.90 ; M=3.27 \text {; } \\
N=10)\end{array}$} \\
\hline . if I slept with someone without starting a serious relationship? & .87 & .83 \\
\hline if I had sexual relations before marriage? & .86 & .81 \\
\hline . if I had one-night stands?* & .85 & .81 \\
\hline - if I were home mates with someone of the opposite sex who is not family?* & .79 & .73 \\
\hline - if I were known as someone whom it is easy to sleep with? & .74 & 69 \\
\hline - if I change boyfriend/girlfriend often? & .71 & .66 \\
\hline - if I wore provocative clothes? & 68 & 61 \\
\hline - if I got divorced and married with someone else?* & .58 & .51 \\
\hline - if I were someone who talks dirty?* & .51 & .49 \\
\hline - if I did something to damage my family's reputation? (Fam) & .48 & .49 \\
\hline \multicolumn{3}{|c|}{$\begin{array}{l}\text { Factor 2: Masculine Honor (Explained variance }=13.09 \% ; \text { Eigenvalue }=3.93 ; \alpha=.87 ; M= \\
4.80 ; N=10 \text { ) }\end{array}$} \\
\hline - if I could not respond when someone humiliates me?* & .77 & 69 \\
\hline - if I did not defend myself when others insult me? & .75 & .65 \\
\hline - if I could not respond when someone ridicules me?* & 69 & .59 \\
\hline - if I were coward?* & 66 & .59 \\
\hline - if I were someone who cannot defend my own rights?* & .63 & .57 \\
\hline . if I were someone with low self-esteem?* & .63 & .59 \\
\hline - if I were weak?* & 61 & .57 \\
\hline - if I could not defend my close friend when he/she was exposed to violence?* & .57 & .51 \\
\hline - if I were unable to protect my partner when someone harasses him/her?* & .57 & .51 \\
\hline if I were unable to support my own family economically? & .55 & .52 \\
\hline
\end{tabular}

Factor 3: Moral Integrity (Explained variance $=9.63 \% ;$ Eigenvalue $=2.89 ; \alpha=.90 ; M=5.23$; $N=10)$

\begin{tabular}{|c|c|c|}
\hline . if I were unfair to someone?* & .80 & .73 \\
\hline - if I were hypocritical?* & .78 & .70 \\
\hline . if I were not honest? & .74 & .69 \\
\hline . if I defamed someone?* & .70 & .65 \\
\hline if I lied to others? & .70 & .64 \\
\hline if I looked after my own interest on every occasion?* & .67 & .61 \\
\hline if I did not keep my word? & .66 & .66 \\
\hline - if I were unreliable?* & .66 & .64 \\
\hline . if I did not pay my debt, even if I had opportunity?* & .66 & .60 \\
\hline . if I rejected someone who ask for help, even if I had opportunity and time?* & .57 & .55 \\
\hline
\end{tabular}

Note. Fam in parenthesis represents the item which was supposed to be in family honor factor. * newly generated items. 
The first analysis with 63 items has revealed a 12-factor model based on the Kaiser's criterion of greater than 1 . This initial model explained $62.42 \%$ of the variance. The scree plot has indicated deviations around component 3 . Therefore, the model was examined with respect to the variance it explained, factor loadings of indicator variables, and reliability; and it was decided that 3-factor model would be the better to fit the data. To test this decision, a parallel analysis was performed with varimax rotation. As a result, 33 items were eliminated because they did not load any of the factors (Henson \& Roberts, 2006), or loaded more than one factors (Costello \& Osborne, 2005), and had communality score below .20 (Child, 2006). Remaining 30 with 3 -factor solution accounted for $52.42 \%$ of the variance and had communalities greater than .37. The factors were examined based on items' features and named as follows: Feminine honor code (10 items); Masculine honor code (10 items); Moral integrity code (10 items). Scale items, factor loadings, eigenvalues, explained variances, item-total correlations and internal reliabilities are summarized in Table 2.

Present factor analysis has demonstrated the relationship of observed items with its underlying factor structure. The results were presented as an indicator of construct validity.

Item-Total Correlations: Results have indicated that the correlation between the factor and its items was between .49 and .83 for the first factor (feminine); .51 and .69 for the second factor (masculine); .55 and .73 for the third factor (moral integrity). Since these values were above .30 (see Tabachnick \& Fidell, 2007) results were taken as satisfactory.

Confirmatory factor analysis: A confirmatory factor analysis was conducted in AMOS 25 (SPSS Inc.) with 30 items checking for the adequacy of the model fit with three factors. The initial Goodness-of-fit indexes were as follows: $\chi^{2}(402)=1181.84, p<.001, \chi 2 / d f=2.94, C F I=.87, R M S E A=.068,90 \% \mathrm{CI}=[.06, .07]$. Modification indices suggested to estimate residual covariances between "if I change boyfriend/girlfriend often?" and "if I had one-night stands?"; between "if I had sexual relations before marriage?" and "if I were home mates with someone of the opposite sex who is not family?"; between "if I wore provocative clothes?" and "if I got divorced and married with someone else?"; between "if I could not respond when someone insults me?" and "if I could not respond when someone ridicules me?"; between "if I were unable to support my own family economically?" and "if I were unable to protect my spouse/boyfriend/girlfriend when someone harasses her/him?"; and between "if I defamed someone?" and "if I did not pay my debt, even if I had opportunity?". The covariances were estimated one at a time. After the modifications, goodness-of-fit indexes were as follows: $\chi^{2}(396)=995.692, p<.001, \chi 2 / d f=2.51, C F I=.90, R M S E A=.060,90 \% \mathrm{CI}=$ $[.05, .06]$. A $\chi 2 / \mathrm{df}$ ratio below 3 is an indicator of an adequate-fitting model (Tabachnick \& Fidell, 2007). The CFI value is .90 , which shows a relatively good fit, and the RMSEA value of .060 indicates an acceptable fit (Hu \& Bentler, 1999). Based on these indices, this data has an acceptable fit to the 3-factor model.

\section{Reliability of HS}

Internal Consistency: Cronbach's alpha coefficient was computed to test internal consistency of the HS. Results have shown that Cronbach's alpha of the scale was .92, which shows that the scale has a very good internal consistency (Tabachnick \& Fidell, 2007). When the reliability of each factor was examined, it was found that the first factor has .90 , the second factor has .87 , the third factor has .90 Cronbach's alpha values (see Table 2). Thus, each of the factors has also sufficient internal consistency. 
The correlation between HS subscales; and between HS and HEI: The correlational analyses showed that there are significant correlations among the subscales of the HS (see Table 3). Feminine honor code subscale is positively correlated with the masculine honor code subscale, and moral integrity code subscale, which were .32 and $.34(p<.001)$, respectively. Similarly, the correlation between the masculine honor code and moral integrity code scales was significant $(r=.45, p<.001)$.

In order to further test the construct validity of the scale, the correlation between Honor Endorsement Index and HI was calculated. As expected, there was a significant correlation between HS and HEI $(r=.43, p<.001)$. Similarly, the correlations between HEI score, and each subscale of HS as feminine, masculine, integrity were statistically significant, .47, .28 $(p<.001)$, and $.14(p<.01)$, respectively. Further, correlations among subscales of HEI (endorsement of woman honor \& endorsement of man honor) and each subscale of HS as feminine, masculine, integrity were calculated. Woman-honor subscale of HEI was correlated with feminine, masculine and integrity subscales, which were $.49, .25(p<.001)$, and $.16(p<.01)$ respectively; and man-honor subscale of HEI was correlated with feminine, masculine and integrity subscales, which were $.43, .29(p<.001)$, and $.13(p<.01)$ respectively.

Correlational analysis with demographic variables: As can be seen in Table 3, gender significantly correlated with feminine honor (women scored higher in feminine honor), and honor endorsement index man/women (men scored higher in honor endorsement index). Age significantly and positively correlated with feminine honor, masculine honor, moral integrity, honor endorsement index man/women, and religiosity. Religiosity significantly and positively correlated with feminine honor, moral integrity, and honor endorsement index man/women. Similar to age, political view (higher rightist) positively correlated with feminine honor, masculine honor, moral integrity, honor endorsement index man/women, and religiosity. As results revealed, economic condition is not related to honor codes or honor endorsement tendency.

Table 3

Correlations among honor scale subfactors, honor endorsement index subfactors and demographics

\begin{tabular}{|c|c|c|c|c|c|c|c|c|c|}
\hline & 1 & 2 & 3 & 4 & 5 & 6 & 7 & 8 & 9 \\
\hline 1. FHC & - & & & & & & & & \\
\hline 2. MHC & $.31 * *$ & - & & & & & & & \\
\hline 3. MIC & $.34 * *$ & $.45^{* *}$ & - & & & & & & \\
\hline 4. HEI-W & $.51 * *$ & $.26^{* *}$ & $.17 * *$ & - & & & & & \\
\hline 5. HEI-M & $.45^{* *}$ & $.29 * *$ & $.13^{* *}$ & $.85^{* *}$ & - & & & & \\
\hline 6. Gender & $.14 * *$ & -.06 & .04 & $-.37 * *$ & $-.39 * *$ & - & & & \\
\hline 7. Age & $.21 * *$ & $.11 *$ & $.12 *$ & $.21 * *$ & $.16 * *$ & -.03 & - & & \\
\hline 8. Religiosity & $.60 * *$ & .06 & $.16^{* *}$ & $.44 * *$ & $.37 * *$ & .03 & $.18^{* *}$ & - & \\
\hline 9. PV & $.43^{* *}$ & $.13 * *$ & $.10^{*}$ & $.38 * *$ & $.35^{* *}$ & -.08 & .07 & $.51^{* *}$ & - \\
\hline 10. EC & .08 & -.01 & .08 & .04 & .02 & .01 & .07 & $.22 * *$ & $.19 * *$ \\
\hline
\end{tabular}

Note. FHC = Feminine honor code MHC = Masculine honor code MIC = Moral integrity code PV = Political view $(1=$ extreme left, to $6=$ extreme right); EC = Economic condition; HEI-W = Honor endorsement index - Women; HEI-W = Honor endorsement index - Men; Gender dummy coded $(0=$ men, $1=$ women $) ; *^{*}<.05, * * p<.001$.

\section{Study 3}

The analyses in Study 2 demonstrated that the HS with the original and newly generated items was a reliable and a valid measurement tool. However, unlike the original study proposed, the scale did not reveal the four factors (feminine, masculine, family, and integrity). Rather, 3-factor solution (feminine, masculine, 
and integrity) fit the data best. One may argue that the difference between the original HS and the Turkish version of HS could be grounded on two different reasons: (1) the difference between two cultures (Spain vs. Turkey), and/or (2) measuring a different construct due to the newly generated items. Therefore, we conducted Study 3 in order to eliminate the possibility that the difference between the original HS and the Turkish version of HS might have been due to the newly added items.

The original HS has been used in a number of studies. For example, Guerra et al. (2013) suggested a short version of the Honor Scale (HS-16) in the Brazilian society. Van Osch, Breugelmans, Zeelenberg, and Bölük (2013) used only family honor and masculine honor items. Howell, Buckner, and Weeks (2015) used original 27 items, but they removed 3 items because of the unsatisfactory factor score weights. However, it should be noted that among those studies, none of them reported an exploratory factor analysis for the HS with all four factors. Only Guerra et al. (2013) and Howell et al. (2015) conducted confirmatory factor analysis. That is to say, to the best of our knowledge, the question of whether the items reveal indeed fourfactor honor structure has never been tested. Therefore, Study 3 offers an important opportunity to advance the understanding of honor factor structure.

\section{Method}

\section{Participants}

Participants consisted of 818 (581 female; 237 male; $\left.M_{\text {age }}=21.30, S D_{\text {age }}=2.15\right)$ undergraduate and graduate university students from different universities in Turkey. Most of the participants were Turkish (87.3\%), Muslim (83.6), single (98\%), and spent their life mostly in metropolis (Ankara, İstanbul, İzmir; $44.9 \%)$. The average socio-economic status of the participants was $4.01(S D=.95)$ on a 6-point scale (1 is poor, 6 is wealthy) indicating a fairly middle class sample.

\section{Measures}

Honor Scale: As explained in Study 2, the original version of the Honor Scale (Rodriguez Mosquera et al., 2002b) included 27 items. However, during the data collection of Study 3, on the website of Rodriguez Mosquera's Culture and Emotion Lab (http://culture-and-emotion.research.wesleyan.edu) in the 'research materials' section, it has been published as 24 items: feminine honor (seven items), masculine honor (six items), family honor (four items), and integrity (seven items). Therefore, in the scope of this study, the HS with 24 items has been used (see Table 4).

\section{Procedure}

The study was approved by the Human Research Ethics Committee of Middle East Technical University. The final version of the scale was uploaded to internet via a software program (Qualtrics, LLC.). The link was shared with people through mail groups, social media, and requests from lecturers in Middle East Technical University, and Ankara University. All of the participants were informed about the study and asked for voluntary participation. Afterwards, they were directed to the researcher in case they need further information. 
Table 4

Factor loadings, item-total correlations, explained variances, eigenvalues, Cronbach's alphas, and items' means per factor

\begin{tabular}{|c|c|c|}
\hline Factor / Item & Factor Loadings & $\begin{array}{c}\text { Item-Total } \\
\text { Correlations } \\
\end{array}$ \\
\hline \multicolumn{3}{|c|}{$\begin{array}{l}\text { Factor 1: Feminine Honor ( Explained variance }=12.19 \% ; \text { Eigenvalue }=2.93 ; \alpha=.87 ; \\
M=4.47 ; N=8)\end{array}$} \\
\hline . if I slept with someone without starting a serious relationship? & .85 & .82 \\
\hline . if I had sexual relations before marriage? & .81 & .79 \\
\hline - if I were known as someone whom it is easy to sleep with? & .72 & .72 \\
\hline . if I had not yet had a sexual relationship? & -.72 & .50 \\
\hline - if I were known as someone who has had many different sexual partners? & .68 & 67 \\
\hline . if I had the reputation of being someone without sexual experience? & -.61 & .36 \\
\hline if I change boyfriend/girlfriend often? & .58 & .63 \\
\hline if I wore provocative clothes? & .49 & .52 \\
\hline \multicolumn{3}{|c|}{$\begin{array}{l}\text { Factor 2: Masculine Honor }(\text { Explained variance }=32.73 \% ; \text { Eigenvalue }=7.86 ; \alpha=.88 \\
M=5.10 ; N=9 \text { ) }\end{array}$} \\
\hline if I lack authority over my own family? & .74 & .64 \\
\hline . if I were known as someone who lacks authority over my own family? & .73 & .63 \\
\hline - if I were unable to defend my family's reputation? (Fam) & .71 & .68 \\
\hline if I did not defend myself when others insult me? & .66 & .62 \\
\hline - if I did something to damage my family's reputation? (Fam) & .65 & .65 \\
\hline if I were unable to support my own family economically? & .63 & .60 \\
\hline . if my sister or mother had the reputation of sleeping around? (Fem) & .62 & .58 \\
\hline . if my family had a bad reputation? (Fam) & .61 & .59 \\
\hline - if I let other people insult my family? (Fam) & .56 & .51 \\
\hline \multicolumn{3}{|c|}{$\begin{array}{l}\text { Factor 3: Moral Integrity ( Explained variance }=9.90 \% ; \text { Eigenvalue }=2.38 ; \alpha=.85 ; M \\
=5.36 ; N=7 \text { ) }\end{array}$} \\
\hline . if I were hypocritical? & .78 & .68 \\
\hline if I did not keep my word? & .78 & .69 \\
\hline if I had the reputation of being dishonest with others? & .72 & .62 \\
\hline if I had the reputation of being someone who is not to be trusted? & .71 & .61 \\
\hline if I betrayed other people? & .70 & .62 \\
\hline if I lied to others? & .70 & .58 \\
\hline . if I were not loyal to my own values and principles? & .50 & .43 \\
\hline
\end{tabular}

Note. Fem and Fam in parenthesis represent the items which were supposed to be in feminine and family honor factors, respectively.

\section{Results}

\section{Validity of HS}

Factor Structure: An exploratory factor analysis was conducted on 24-item HS. The Kaiser-Meyer-Olkin (KMO) and Bartlett's Test of Sphericity have shown that data is convenient for the factor analysis, $K M O=$ $.90, \chi 2(276)=5407.51, p<.001$ (Tabachnick \& Fidell, 2007). The maximum number of iterations was set as 30 and the cut-off point for loadings was set at .40 . 
The analysis with 24 items has revealed a 4 -factor model based on the Kaiser's criterion of greater than 1. This model explained $59.83 \%$ of the variance. However, the items did not load on factors as suggested in literature, that is, only two items ("if I had not yet had a sexual relationship", and "if I had the reputation of being someone without sexual experience"), which belonged to masculinity code loaded on the fourth factor. Since there were only two items in a factor, and scree plot graphic suggests a 3-factor model, the data was forced into 3-factor model. As a result, those two-items which were supposed to be in masculine code loaded reversely into feminine code, and items were distributed as follows: Feminine-honor code (8 items); Masculine-honor code (9 items); and Integrity-honor code (7 items). Scale items, factor loadings, eigenvalues, explained variances, item-total correlations and internal reliabilities are summarized in Table 4. In conclusion, 24 items with 3-factor solution accounted for 54.83\% of the variance and had communalities greater than 29 .

Confirmatory Factor Analysis: A confirmatory factor analysis was performed to test the hypothesis that a relationship between observed variables and their underlying latent constructs (feminine, masculine, and integrity) exists; and secondly, to test whether the three-factor model fits the honor concern data well. The average off-diagonal absolute standardized residual was .043. Distribution of standardized residuals figure demonstrated that $100 \%$ of residuals fall between $\mathrm{z}$-scores of -0.1 and +0.1 . Afterwards, maximum likelihood estimation was employed to estimate the model. It was found that our model did not fit the data very well, $\chi^{2}(164)=562.90, p<.001, C F I=.92, R M S E A=.055,90 \%$ CI $[.05, .06]$, Rho $=.91$.

Measurement equations showed that all of the indicators had significant regression coefficients; factor loadings were ranging from $\beta=.58$ to $\beta=.86$ for the feminine factor, from $\beta=.57$ to $\beta=.93$ for the masculine factor, and from $\beta=.67$ to $\beta=.74$ for the integrity factor. The covariance between independent variables, feminine and masculine was $r=-.51$; feminine and integrity was $r=.37$; and masculine and integrity was $r=-.14$.

Post hoc model modification was performed in an attempt to develop a better fitting model. On the basis of the Lagrange Multiplier (LM) test, residual covariance between "if I slept with someone without starting a serious relationship?" and "if I had sexual relations before marriage?" was estimated, $\chi^{2}(1)=$ $88.98, p<.001$; residual covariance between "if I had the reputation of being someone who is not to be trusted?" and "if I had the reputation of being dishonest with others?" was estimated, $\chi^{2}(2)=67.69, p<$ .001 ; residual covariance between "if I had sexual relations before marriage?" and "if I wore provocative clothes?" was estimated, $\chi^{2}(3)=53.92, p<.001$; residual covariance between "if I change boyfriend/girlfriend often?" and "if I wore provocative clothes?" was estimated, $\chi^{2}(4)=22.48, p<.001$; and residual covariance between "if I lied to others?" and "if I did not keep my word?" was estimated, $\chi^{2}(5)=$ $21.25, p<.001$. It was hypothesized that when we let those errors be correlated, $\chi^{2}$ will decrease, implying a good improvement.

According to the Lagrange Multiplier (LM) test results, model-2 was run with modifications stated above. After modifications, it was found that our model fit the data very well, $\chi^{2}(159)=387.98, p<.001$, $C F I=.96, R M S E A=.04,90 \%$ CI $[.04, .05], R h o=.91$. After modification, it was examined whether there was statistically significant improvement in model-2 over model-1. Results suggested that model-2 was significantly better than model- $1, \Delta \chi^{2}(5)=174.92, p<.001$. 
Item-Total Correlations: Results have indicated that the correlation between the factor and its items was between .36 and .82 for the first factor (feminine); .51 and .68 for the second factor (masculine); .43 and .69 for the last factor (integrity). Since these values were above .30 (see Tabachnick \& Fidell, 2007) results were taken as satisfactory.

\section{Reliability of HS}

Internal Consistency: Cronbach's alpha coefficient was computed to test internal consistency of the HS. Results have shown that Cronbach's alpha of the scale was .90, which shows that the scale has a very good internal consistency (Tabachnick \& Fidell, 2007). When the reliability of each factor was examined, it was found that the first factor has .87 , the second factor has .88 , and the last factor has .85 Cronbach's alpha values (see Table 4). Thus, each of the factors has also sufficient internal consistency.

Split-half Reliability: In order to test reliability via split-half method, the items were split into two for each functions, and the correlation between them was examined. According to the analysis on feminine code including 8 items, the correlation between the first part composed of 4 items and the second part composed of 4 items is $r=.73$; Guttman Half-split reliability score was .81. Similarly, according to the analysis on masculine code including 9 items, the correlation between the first part composed of 5 items and the second part composed of 4 items is $r=.72$; Guttman Half-split reliability score was .80 . Finally, according to the analysis on integrity code including 7 items, the correlation between the first part composed of 4 items and the second part composed of 3 items was $r=.72$; Guttman Half-split reliability score was found to be .81 . Based on these results, it can be suggested that the scale has the half-split reliability.

\section{Discussion}

The aim of the current study was to adapt HS (Rodriguez Mosquera et al., 2002b) into Turkish culture, by adding also the culture-congruent items. Before testing the validity and the reliability of HS, we conducted a semi-structured interview to generate new culture-specific items (Study 1) because we assumed that Spanish and Turkish cultures might have had different characteristics. Then, HS and the new items were tested together to examine the reliability and the validity for Turkish culture (Study 2), and this study revealed a 3-factor honor structure unlike the original scale with 4-factor honor structure. Finally, we tested this 3-factor honor structure with only original items of HS (Study 3) to eliminate a possible criticism stating that the differences in factor structure might have been due to adding new items into the original HS.

Exploratory and confirmatory factor analyses of two studies revealed that a 3 -factor solution (feminine, masculine, and moral integrity) fits the data best, by eliminating the family honor code in Turkish culture. The feminine honor factor included items about sexual activities before marriage, sexual chastity, and family reputation. These issues seem to be relevant to the expected roles of women in Turkish culture. This finding is consistent with previous studies on the premarital sexuality (Sakalli-Uğurlu \& Glick, 2003) and women's honor (namus) (see Işık \& Sakal1-Uğurlu, 2009). The masculine honor factor consists of items relevant to the concerns about masculine gender roles such as being weak, not being able to support a family economically, not defending or protecting women in their family. They reflect stereotypes about men in Turkish culture. As Sakall1-Uğurlu, Türkoğlu, Kuzlak, and Gupta (2018) presented, Turkish men are perceived as strong, protective, and supportive of their family. If men cannot fulfill the gender roles, they 
may perceive their honor/manhood under threat. This is consistent with the literature on male gender role stress (Eisler \& Skidmore, 1987). The moral integrity factor contains items about being honest, fair, trustworthy, and reliable. These items indicate general moral issues, which are likely to be accepted in every culture. As the literature suggests, the construct of honor is usually defined as having a good moral character, integrity, virtuous behavior, and altruism for both males and females in almost all cultures. These behaviors are also relevant to status, power, strength, and a good reputation of a person (Nisbett \& Cohen, 1996; Vandello \& Cohen, 2003).

The three-factor structure was not consistent with the four-factor structure of the original HS (Rodriguez Mosquera et al., 2002b). The family honor factor of the original HS disappeared in the Turkish data. Items of family honor code mostly disappeared in Study 2 (only 1 item loaded on the feminine honor factor), and loaded on the masculine honor factor in Study 3. The results may suggest that individuals, both women and men, are not perceived as independent entities from their families. The status of each member is seen strongly relevant to his or her family. In addition, behaviors of women and men are perceived as reflection of their general family attitude. The findings, in fact, are consistent with the literature on gender stereotypes and honor issues. In honor cultures, the family is regarded as the central unit in the society, which should be maintained by any means (e.g., Haj-Yahia, 2002; Malina, 2001). Therefore, individuals are not considered as independent from their families so that their identity mostly internalized with their family. In a similar vein, the reputation of an individual and the reputation of his/her family are highly interdependent (Moxnes, 1996; Rodriguez Mosquera et al., 2002b). Members are representing not only their own honor, but also their family's honor. In this regard, honor-oriented or dishonorable behaviors of men and women gain crucial importance by affecting the total family honor in Turkey.

Both gender-specific honor codes (feminine and masculine) play significant role in constituting the family honor (Rodriguez Mosquera et al., 2002a, 2002b). More specifically, feminine honor seems to be nested in man honor, then in family honor; it is the woman's chastity, which determines man's honor, and both form the family reputation. When a family member, especially a woman violates a feminine honor code, it means that she also violates the family honor and contaminate the family name (see Sakall1-Uğurlu $\&$ Akbaş, 2013). Therefore, in honor cultures like Turkey, family honor does not seem to be an independent construct. When we consider this interwoven structure of gender-specific honor codes and family honor codes, it is more understandable why the tetrad-honor structure does not appear in Turkish culture. Apparently, the family honor in Turkey has been defined through the feminine and the masculine, or even the integrity honor codes. However, further research is needed to examine whether this three-factor structure exists only in Turkish culture or in the other honor cultures as well. To the best of our knowledge, fourfactor structure of the original HS has never been analyzed through an exploratory factor analysis before. Therefore, this difference between cultures requires further investigation.

In Study 2 correlational analyses among HS, HEI and demographic variables were performed to examine validity of HS. Results showed that HEI-W and HEI-M were correlated with feminine, masculine and moral integrity honor factors. The correlation values varied from .13 to .51 (see Table 3 ). The results may present that HS measures different constructs from HEI, but they are relevant to each other. Feminine honor code seems to be more correlated with HEI-W and HEI-M. This may be due to similarity between HS and HEI on items about women's honor (namus). Both scale cover issues about how women should avoid attitudes and behaviors in relation to sexuality. 
Further, gender was correlated with feminine honor, but not with masculine honor. This finding is consistent with Rodriguez Mosquera et al. (2002b) who found that there was not gender difference in terms of masculinity honor. It seems that masculine gender roles are similarly accepted by men and women. This result may suggest that items such as "if I were someone who cannot defend my own rights" or "if I could not respond when someone insults me" are equally important concerns for both men and women.

Another finding worth to be discussed is the relation between honor related concerns and demographic variables such as religiosity level and political view. Economic condition was not correlated with any of honor relevant scales. However, honor concerns were correlated with religiosity and political view. People with high religiosity level and rightist political view tended to highly agree with feminine, masculine and moral integrity honor codes. The religiosity result was similar to the findings of Glick et al. (2016) in which religiosity was correlated with honor endorsement. Similarly, people with right political view may aim to protect honor values as well as traditional values. They may tend to justify social hierarchy and the gender status quo (Kay \& Jost, 2003). In general, our findings seem to be consistent with the literature on religiosity and political views relevant to sexism and honor in Turkish culture (Glick et al., 2016; Sakallı Uğurlu \& Özdemir, 2017), and so the results from demographic variables support validity of HS.

In general, the analyses demonstrated that both HSs (with only original items and with both original and generated items) were reliable and valid measurement tools. However, the 4-factor structure of original HS (Rodriguez Mosquera et al., 2002b) did not appear the same in Turkish culture. The difference between original scale and new scale could be grounded on measuring a different construct due to newly generated items. However, in Study 3 the same result (3-factor structure) has been obtained again. This finding revealed that in Turkish culture, honor is a multifaceted construct but it is likely to have three components rather than four. Further studies are needed to confirm this finding.

For testing reliability of 3-factor structure, we computed Cronbach's alpha coefficient to test internal consistency of each factors of HS. Results were satisfactory, and meeting the criteria of greater alpha values than .70 (Tabachnick \& Fidell, 2007). However, test-re-test reliability was not examined for both of the study. Future studies may examine the time consistency.

Lastly, in study 2 and Study 3, although the sample is large enough, it is essential to bear in mind that the sample is composed of participants with limited range of education level (i.e., university student or graduates), living in big cities, from middle or high SES families. It is unfortunate that the study did not include a wider segment of population, however, further work can examine attitudes of individuals from a broad range of age group (e.g., elders), socioeconomic status (e.g., low SES), residential areas (e.g., slums in cities), settlements (e.g., rural areas), and locations (e.g., other countries of honor culture).

Despite of the limitations above, since the validity and reliability results are within satisfactory range, we can conclude that both versions of HSs are valid and reliable scales in Turkish culture. The scale can be used to study honor issues in Turkey and in cross-cultural studies. 


\section{References}

Abu-Lughod, L. (1986). Veiled sentiments: Honor and poetry in a Bedouin society. Berkeley: University of California Press.

Akbaş, G. (2016). The effect of system justification and regulatory focus orientation in the endorsement of honor and honor based violence. Unpublished $\mathrm{PhD}$ thesis. Middle East Technical University, Ankara-Turkey.

Barnes, C. D., Brown, R. P., \& Osterman, L. L. (2012). Don't tread on me. Personality and Social Psychology Bulletin, 38, 1018-1029.

Barnes, C. D., Brown, R. P., Lenes, J., Bosson, J., \& Carvallo, M. (2014). My country, my self: Honor, identity, and defensive responses to national threats. Self and Identity, 13, 638-662.

Bettiga-Boukerbout, M. G. (2005). 'Crimes of honour' in the Italian Penal Code: an analysis of history and reform. In L. Welchman \& S. Hossain (Eds.), 'Honor' crimes, paradigms, and violence against women, (pp. 230-244). London: Zed Books.

Child, D. (2006). The essentials of factor analysis. (3rd ed.). New York, NY: Continuum International Publishing Group.

Costello, A. B., \& Osborne, J. W. (2005) Best practices in exploratory factor analysis: Four recommendations for getting the most from your analysis. Practical Assessment, Research \& Evaluation, 10, 1-9.

Eisler, R. M., \& Skidmore, J. R. (1987). Masculine gender role stress: Scale development and component factors in the appraisal of stressful situations. Behavior Modification, 11, 123-136.

Elgin, V. M. (2016). Examining honor culture in Turkey: Honor, manhood, \& man-to-man response to insult. Unpublished PhD thesis. Middle East Technical University, Ankara-Turkey.

Fischer, D. H. (1989). Albion's seed: Four British folkways in America. New York: Oxford University Press.

Glick, P., Sakall1-Uğurlu, N., Akbaş, G., Orta, İ. M., \& Ceylan, S. (2016). Why do women endorse honor beliefs? Ambivalent sexism and religiosity as predictors. Sex Roles, 75(11-12), 543-554

Gregg, G. S. (2005). The Middle East: A cultural psychology. New York: Oxford University Press.

Gregg, G. S. (2007). Culture and identity in a Muslim society. New York, NY: Oxford University Press.

Guerra, V. M., Gouveia, V. V., Araújo, R. C., Andrade, J. M., \& Gaudêncio, C. A. (2013). Honor Scale: Evidence on construct validity. Journal of Applied Social Psychology, 43, 1273-1280.

Haj-Yahia, M. (2002). Beliefs of Jordanian women about wife beating. Psychology of Women Quarterly, 26, 282-291.

Henson, R. K., \& Roberts, J. K. (2006). Use of Exploratory Analysis in Published Research: Common Errors and Some Comments on Improved Practice. Educational and Psychological Measurement, 66, 393416.

Howell, A. N., Buckner, J. D., \& Weeks, J. W. (2015). Culture of honour theory and social anxiety: Crossregional and sex differences in relationships among honour-concerns, social anxiety and reactive aggression. Cognition and Emotion, 29, 568-577.

Hoyek, D., Sidawi, R. R., \& Mrad, A. A. (2005). Murders of women in Lebanon: 'Crimes of honour' between reality and law. In L. Welchman \& S. Hossain (Eds.), 'Honor' crimes, paradigms, and violence against women, (pp. 111-136). London: Zed Books.

Hu, L., \& Bentler, P. M. (1999). Cutoff criteria for fit indexes in covariance structure analysis: Conventional criteria versus new alternatives. Structural Equation Modeling, 6, 1-55. 
Işık, R., \&. Sakallı-Uğurlu, N. (2009). Namusa ve namus adına kadına uygulanan şiddete ilişkin tutumlar ölçeklerinin öğrenci örneklemiyle geliştirilmesi. Türk Psikoloji Yazıları, 12(24), 16-24.

Kardam, F. (2005). The dynamics of honor killings in Turkey: Prospects for action. Ankara: UNFPA.

Kay, A. C., \& Jost, J. T. (2003). Complementary justice: Effects of "poor but happy" and "poor but honest" stereotype exemplars on system justification and implicit activation of the justice motive. Journal of Personality and Social Psychology, 85, 823-837.

Kulwicki, A. D. (2002). The practice of honor crimes: A glimpse of domestic violence in the Arab world. Issues in Mental Health Nursing, 23, 77-87.

Malina, B. J. (2001). The new testament world: Insights from cultural anthropology. Westminster: John Knox Press.

Miller, D. T., \& Prentice, D. A. (1994). The self and the collective. Personality and Social Psychology Bulletin, 20(5), 451-453.

Moxnes, H. (1996). Honor and Shame. In R. L. Rohrbaugh. (Ed.), The social sciences and new testament interpretation, (pp. 19-40). Peabody: Hendrickson Publishers.

Nisbett, R. E., \& Cohen, D. (1996). Culture of honor: The psychology of violence in the South. Boulder, CO: Westview Press.

Peristiany, J. G. (Ed.). (1965). Honour and shame: The values of Mediaterranean society. London: Weidenfeld \& Nicholson.

Pitt-Rivers, J. (1965). Honour and social status. In J. Peristiany (Ed.), Honour and shame: The values of Mediterranean society (pp. 19-77). London: Weidenfeld \& Nicholson.

Prentice, D. A., \& Miller, D. T. (1996). Pluralistic ignorance and the perpetuation of social norms by unwitting actors. Advances in Experimental Social Psychology Volume 28, 161-209.

Rodriguez Mosquera, P. M., Fischer, A. H., Manstead, A. S. R., \& Zaalberg, R. (2008). Attack, disapproval, or withdrawal? The role of honour in anger and shame responses to being insulted. Cognition and Emotion, 22, 1471-1498.

Rodriguez Mosquera, P. M., Manstead, A. S. R., \& Fischer, A. H. (2002a). Honor in the Mediterranean and Northern Europe. Journal of Cross-Cultural Psychology, 33, 16-36.

Rodriguez Mosquera, P. M., Manstead, A. S. R., \& Fischer, A. H. (2002b). The role of honor concerns in emotional reactions to offences. Cognition \& Emotion, 16, 143-163.

Sakallı-Uğurlu, N., \& Akbaş, G. (2013). Namus kültürlerinde "namus" ve "namus adına kadına şiddet": Sosyal psikolojik açılklamalar. Türk Psikoloji Yazıları, 16(32), 76-91.

Sakall1-Uğurlu, N., \& Glick, P. (2003). Ambivalent sexism and attitudes toward women who engage in premarital sex in Turkey. The Journal of Sex Research, 40(3), 296-302.

Sakall1-Uğurlu, N., \& Özdemir, F. (2017). Predicting attitudes toward the masculine structure

of the military with Turkish identification and ambivalent sexism. Sex Roles,76, 511519. doi: 10.1007/s11199-016-0676-0

Sakalli-Uğurlu, N., Türkoğlu, B., Kuzlak, A., \& Gupta, A. (2018). Stereotypes of single and married women and men in Turkish culture. Current Psychology. https://doi.org/10.1007/s12144-018-9920-9

Sen, P. (2005). 'Crimes of honor', value and meaning. In L. Welchman \& S. Hossain (Eds.), 'Honor' crimes, paradigms, and violence against women, (pp. 42-63). London: Zed Books.

Sev'er, A., \& Yurdakul, G. (2001). Culture of honor, culture of change: A feminist analysis of honor killings in Turkey. Violence Against Women, 7, 964-998. 
Tabachnick, B. G., \& Fidell, L. S. (2007). Using multivariate statistics, 5th ed. Boston, MA: Allyn and Bacon.

Thompson, E. H., \& Pleck, J. H. (1986). The structure of male role norms. American Behavioral Scientist, 29, 531-543.

Üskül, A. K., Cross, S. E., Sunbay, Z., Gerçek-Swing, B., \& Ataca, B. (2012). Honor bound: The cultural construction of honor in Turkey and the Northern United States. Journal of Cross Cultural Psychology, 43, 1131-1151.

Van Osch, Y., Breugelmans, S. M., Zeelenberg, M., \& Bölük, P. (2013). A different kind of honor culture: Family honor and aggression in Turks. Group Processes and Interpersonal Relations, 16, 334-344.

Vandello, J. A., \& Cohen, D. (2003). Male honor and female fidelity: Implicit cultural scripts that perpetuate domestic violence. Journal of Personality and Social Psychology, 84, 997-1010.

Vandello, J. A., Cohen, D., Grandon, R., \& Franiuk, R. (2009). Stand by your man: Indirect prescriptions for honorable violence and feminine loyalty in Canada, Chile, and the United States. Journal of CrossCultural Psychology, 40, 81-104. 